\title{
Joanna Marszałek-Kawa
}

Nicolaus Copernicus University (Poland)

\author{
Ahmet Burak \\ Nicolaus Copernicus University (Poland)
}

\section{Turkey's View of President Recep Tayyip Erdoğan's Visit to Poland in 2017. Prospects and Conclusions}

\begin{abstract}
On October 17, 2017, President of Turkey Recep Tayyip Erdoğan paid an official visit to Warsaw upon the invitation of the President of the Republic of Poland Andrzej Duda. The main subject of the talks was political, economic and cultural cooperation. Issues of security were also addressed. President Erdoğan had last visited Warsaw during the NATO summit on July 8-9, 2016. During the meeting in October, the two presidents signed five bilateral agreements. This paper provides an analysis of the effects of President Recep Tayyip Erdoğan's visit and prospects regarding the development of friendly relations between Poland and Turkey from Ankara's perspective. In the paper we applied the test analysis method, the historical method and the institutional and legal one. We pose a thesis that the aim of President Recep Tayyip Erdoğan's visit was to identify mutual relations in the economic, political and cultural dimension. According to the Turkish government, these relations are beneficial for both sides. What should be particularly important for Poland is the prospect of opening new cooperation opportunities in the economic sphere. Turkey, in turn, apart from defining the broad framework of business cooperation, is undoubtedly determined to find a partner which could be its ally in the European Union.
\end{abstract}

Keywords: Republic of Turkey, Republic of Poland, Recep Tayyip Erdoğan, Andrzej Duda, economic relations, visit

Poland and Turkey have maintained long-term bilateral diplomatic relations for more than six hundred years. This fact has been often emphasized during official talks on the diplomatic level and in scientific and cultural circles. In 1923 the Treaty on Polish-Turkish Friendship was signed in Lausanne (Traktat o Przyjaźni..., 1924). Although its provisions are still binding, there is no doubt that its role is fairly symbolic today. This document was updated 
in 1993 in Warsaw (Układ o przyjaźni i współpracy..., 1995). It was agreed then that issues concerning new conditions of cooperation would be regulated in new documents.

After the fall of communism in Poland, each consecutive president of Turkey has paid an official visit to Warsaw. Polish presidents also visited Turkey. In 2009 Recep Tayyip Erdoğan, the-then prime minister, came to Poland with an official visit. It should be noted that it was the head of the Turkish government's first official visit in Poland since 1923 (premier.gov.pl, 2009). Official media statements emphasized that the Warsaw meeting between President Erdoğan and President of the RP Andrzej Duda on October 17, 2017 was the expression of traditional friendship between the two nations and states. It is worth noting here that the last phone talk between Recep Tayyip Erdoğan and Andrzej Duda took place on April 24, 2017. It was initiated by Erdoğan and its subject was the course and results of the constitutional referendum in Turkey. Issues related to the further stages of the constitutional reform of the Turkish state were also addressed (prezydent.pl, 2017a). What is important, President Andrzej Duda was one of the few heads of state that President Erdoğan talked to after the referendum. Less than a month later, on May 14,2017, Erdoğan had an unexpected meeting with Polish Prime Minister Beata Szydło at the Belt and Road Forum in China. The government's spokesman, Rafał Bochenek, said that both politicians had discussed issues of the European agenda, especially those concerning the European Union's immigration policy. At the meeting, the issue of increasing trade volume between Poland and Turkey was also addressed (dziennik.pl,2017a).

Before his visit to Poland in October, President Erdoğan had held three important meetings. On October 6, 2017, he met with the president of Venezuela, Nicolás Maduro, in Ankara (Türkiye Cumhuriyeti Cumhurbaşkanlığı, 2017a). Earlier, the Venezuelan president had visited Russia and Belarus (Газета.ru, 2017). During the negotiations in Ankara the presidents expressed their support for the construction of a multipolar world, as opposed to the dictates of the "sole political power" (РИА Новости, 2017). Alfredo Serrano Mancilla stressed that the meeting of Nicolas Maduro with the president of Turkey had enormous geopolitical and geoeconomic value. Turkey is an important player on the international arena. Europe is observing its developing economy with a growing interest. Cooperation with Turkey must be based on mutual benefits in such spheres as agriculture, technology, finances, mining, tourism, transport, and security (Мансилья, 2017). The second meeting was held on October 9,2017 in Kiev, Recep Tayyip Erdoğan talked to the president of Ukraine, Petro Poroshenko (Türkiye Cumhuriyeti Cumhurbaşkanlığı, 2017b). Two weeks earlier, the president of Turkey met with the president of Russia, Vladimir Putin. Experts in Ukraine and Turkey emphasize that the government in Ankara is designing its policy trying to balance the interests of two conflicting countries (Дорош, 2017). During his official visit in Kiev, President Erdoğan said that Ankara did not recognize Crimea's accession to the Russian Federation (lenta.ru, 2017). Russia obviously responded to Erdoğan's words concerning the annexation. The spokeswoman for the Russian ministry of foreign affairs, Maria Zakharova, said that "anyone's statements concerning the recognition or non-recognition of Crimea 
will not change the fact that Crimea is a part of Russia". She also added that "partners are different and they are driven by different interests" (ИноСМИ.ru, 2017). It should be noted that issues related to economic development prevailed during the Ukrainian-Russian talks. Political subjects were treated marginally. It must be stressed that Turkey finds Russia an incomparably more important strategic partner than Ukraine. However, friendship in politics is a matter which is subject to frequent changes and it should be emphasized that consistent efforts aimed at developing economic ties between Ukraine and Russia contribute to the strengthening of relations between the two countries. According to Turkish politicians, when trade exchange between Ukraine and Turkey reaches the level of a few dozen billion dollars - as it is the case with Turkish-Russian business cooperation - the relations with Ukraine may start to be seen by Ankara in a much more positive light. There is no doubt that Ukraine's economic potential is large, but the problem is how to make use of it (Kamalov, Kanbolat, 2012).

Shortly before his official visit in Poland, on October 10, 2017, the president of Turkey met with the president of Serbia, Alexandar Vučić, in Belgrade (Türkiye Cumhuriyeti Cumhurbaşkanlığı, 2017c). Their talks concerned mainly economic affairs. Erdoğan's delegation consisted of eight ministers and 185 Turkish entrepreneurs interested in investment in Serbia (CNN Türk, 2017a). During the three-day visit, the two sides signed 12 agreements, including the statement of the revision of the free trade agreement and documents concerning cooperation in the spheres of energy, urban planning, transport and infrastructure, forestry, and water management. The presidents of both countries initiated a joint political declaration on the establishment of the supreme board of cooperation between Serbia and Turkey. The government in Ankara expects that the "Turkish Stream" gas pipeline will be extended to Serbia. Erdoğan said that Belgrade wanted to receive gas via this route from 2019 (Regnum, 2017; tass.ru, 2017).

As it was emphasized before, all meetings preceding the visit in Warsaw focused on the issues of economic cooperation. Similar subjects were also discussed in Warsaw. Turkish press noted that the aim of Erdoğan's visit in Poland was to establish the foundations for the development of trade cooperation between the two countries. For example, TRT Haber wrote “İş dünyasının gözü Cumhurbaşkanı Erdoğan’n Polonya ziyaretinde” (Eng. businessmen are waiting for President Erdoğan's visit in Poland) (TRT Haber, 2017); Habertürk "İş adamlarımızı Polonyaya davet ediyorum" (Eng. businessmen - we invite you to Poland) (Habertürk, 2017b); Anadolu Ajansi "Polonya ile 10 milyar dolarlık ticaret hedefi" (Eng. trade with Poland, target: 10 billion dollars) (Anadolu Ajans1, 2017), etc.

It should be reminded that the Turkish president's visit to Warsaw on October 8, 2017 had been prepared in the atmosphere of a diplomatic scandal, which broke out between Washington and Ankara. Its direct cause was the arrest of an employee of the US Consulate General in Istanbul, a Turkish citizen, Metin Topuz, by the Turkish authorities on October 4. He was accused of spying and belonging to the group involved in an unsuccessful attempt of a coup in July 2016 (CNN Türk, 2017b). The United States responded to the arrest of Metin 
Topuz by suspending the issue of visas to Turks, and Turkey did the same for US citizens in return (Sabah, 2017a).

It should be noted here that Turkey is a member of the NATO and for decades Turkey has been a candidate for EU membership. What is a barrier to becoming a member state are its strained relations with some European countries. When a correspondent of German newspaper "Die Welt", Deniz Yucel, was arrested in Turkey on February 27, 2017, the relations between Germany and Turkey became even tenser (DW,2017a). In March 2017, the conflict between Turkey and the Netherlands escalated after the government representatives, who wanted to meet with Turkish demonstrators expressing their approval for President Erdoğan, were refused the entry to the Dutch territory. It was the minister of foreign affairs, Mevluta Cavusoglu, who received a landing ban (Sputnik, 2017a). As a result, a diplomatic conflict broke out between the two countries and the Turkish government decided to suspend diplomatic relations with the Netherlands temporarily. In light of these events, the European Parliament ran another debate on the suspension of membership negotiations with Turkey. It is worth reminding here that the dispute over the relations between Turkey and Austria, the starting ground for which was a motion submitted by Austrian politicians, concerned the suspension of negotiations on Turkey's accession to the European Union. In revenge, Turkey blocked Austria's participation in NATO partnership programmes, which additionally exacerbated the already tense situation (Бухарова, 2017).

According to Samim Akgönül, Turkey began seeking alternative strategic partners a long time ago. What moved Ankara closer to Russia was the involvement of Russian troops in the Syrian conflict. Akgönül indicates, however, that no other alliances can replace Turkey's relations with the European Union, which is its main economic partner, after all (Sputnik, 2017b; Burak, 2015, pp. 56-66).

It should be mentioned here that on June 23, 2016, UK citizens voted to leave the European Union. For Turkey Brexit means losing a very important ally in its efforts to access the EU. It is also a signal which shows the weakness of the European structures and makes us reflect on the direction of changes in Europe (Marszałek-Kawa, Burak, 2017a,pp. 117-126).

Facing a difficult internal and international situation of Turkey, on October 17, 2018, President of Turkey Recep Tayyip Erdoğan began his one-day visit in Warsaw. The government spokesman, Rafał Bochenek, said that the visit of the Turkish head of state was important for the ongoing process of the strengthening of the eastern wing of the North Atlantic Treaty Organization, in which Turkey is a significant point of reference. Bochenek emphasized that the aim of the meeting was to discuss the development of cooperation in the course of the implementation of the agreement signed between the European Union and Turkey concerning the migration wave from the Middle East (wPolityce.pl, 2017).

At the official welcome of the Turkish delegation, a military orchestra played a piece composed by Dede Efendi (1778-1846), entitled Ey büt-i nev edâ (Sabah, 2017b). President Recep Tayyip Erdoğan was accompanied by Minister for European Affairs Ömer Çelik, 
Minister of Labor and Social Security Jülid Sarıeroğl, Minister of Foreign Affairs Mevlüt Çavuşoğl, Minister of Economy Nihat Zeybek, Minister of Energy and Natural Resources Berat Albayrak (husband of the oldest daughter of President Recep Tayyip Erdoğan), Minister of Culture and Tourism Numan Kurtulmuş, and Minister of Defense Nurettin Canikli (Habertürk, 2017a).

Before a press conference, in the presence of two presidents - Andrzej Duda and Recep Tayyip Erdoğan - members of the governments of both countries signed documents concerning mutual cooperation, i.e. five international agreements regarding, among others, cultural and military issues:

- Memorandum of Understanding between the Ministry of Foreign Affairs of the Republic of Poland and the Ministry of Foreign Affairs of the Republic of Turkey on Cooperation in the Field of Diplomatic Archives,

- Declaration of Intent between the Ministry of National Defense of the Republic of Poland and the Ministry of National Defense of the Republic of Turkey,

- Agreement between the Republic of Poland and the Republic of Turkey on Social Security,

- Administrative Agreement concerning the Implementation of Agreement between the Republic of Poland and the Republic of Turkey on Social Security,

- Implementation Programme for the Agreement between the Government of the Republic of Poland and the Government of the Republic of Turkey on Cooperation in the Fields of Science, Education and Culture for 2017-2020 (prezydent.pl,2017c).

It should be stressed that the agreement on social security is one of the most important documents signed by both governments. As the Ministry of Family, Labor and Social Policy informed on its website,"the agreement between Poland and Turkey on social security fits in the EU policy concerning the external dimension of social security system coordination. The agreement covered: unemployment benefits, child benefits (with the exclusion of a one-off benefit on the birth of a child), benefits related to illness, maternity, old age (pensions), inability to work (disability pensions), industrial accidents and job-related illnesses (benefits resulting from the temporary incapacity for work, disability pensions, compensation), and death benefits (family pensions, funeral allowances). The agreement will also be applicable for the legislation concerning obligatory insurance" (Ministry of Family, Labor and Social Policy, 2017). There is no doubt that the provisions of this long-awaited agreement will be helpful for Turkish citizens living in Poland. What is equally important, the Implementation Programme for the Agreement between the Government of the Republic of Poland and the Government of the Republic of Turkey on Cooperation in the Fields of Science, Education and Culture for 2003-2006 was signed by the Polish side in Ankara on April 7, 2003 (Program realizacji umowy..., 2004). Following the meeting in Warsaw in October, it was prolonged to 2020 (Program realizacji umowy..., 2004).

Speaking together at a press conference, R.T. Erdoğan and A. Duda stressed that both countries have maintained diplomatic relations for over 600 years. They emphasized that 
Turkey has never recognized the partitions of Poland (polskieradio.pl, 2017). Andrzej Duda pointed out that Polish people would always remember that the keys to the Polish embassy to the Ottoman Empire that had been lodged with the sultan had always been safe there and the embassy has never been handed over to anyone nor has it been destroyed, waiting for the return of the Polish ambassador. After Poland regained independence in 1918, the ambassador came back to Ankara and collected the keys to the embassy building from the last sultan of Ottoman Turkey (prezydent.pl, 2017b).

During the talks, the issue of difficult relations between Turkey and the European Union was addressed. President Andrzej Duda declared his support for the Turkish government's efforts in the negotiation process: "Poland has always backed Turkey in its attempts to join the European Union; Turkey is the EU's extremely important partner in security issues" (TVP Info, 2017b).

On the other hand, it must be noted that Turks themselves are becoming less and less confident that their country may become an EU member state. On October 1,2017, President Erdoğan gave a speech in the Turkish parliament in which he said that Turkey no longer needed membership in the European Union, but it would not abandon accession talks, which had reached a dead end (TVP Info, 2017a). Two weeks later he said in Warsaw: „If you want to admit Turkey to the EU, just tell us that; if you don't want it to happen, tell us that" (gazetaprawna.pl, 2017).

At the meeting, the presidents also discussed the issue of Ukraine's integrity and problems in the NATO. President Duda said: "we do want Turkey's support when it comes to the policy of the North Atlantic Treaty Organization, when it comes to the strengthening of the eastern wing of the NATO". Both leaders agreed that the issue of Ukraine is not the main goal of the NATO and the European Union. They stressed, however, that Ukraine should regain its territorial integrity and control over its borders, in accordance with international agreements and international law (niezalezna.pl, 2017b).

According to Turkish press, the visit of the president of Turkey concerned mainly bilateral economic relations. Andrzej Duda pointed out that economic cooperation between the two countries is quite intensive. In 2011-2013, the volume of trade between Poland and Turkey increased by $5 \%$ a year, and in 2016 it reached the amount of six billion euro. It should also be mentioned that the need for increasing tourist exchange was also stressed at the meeting (gospodarkamorska.pl, 2017). Moreover, President Erdoğan raised the issue of the development of mutual relations in the sphere of defense (Rzeczpospolita, 2017). The chairman of the Polish-Turkey Chamber of Commerce, Kemal Güleryüz, expressed his expectation that the common target of both countries should be to increase bilateral trade volume from six to 10 billion euro. In future, Turkey wants to invest more in Polish construction industry, which is subsidized by the European Union (DW, 2017b).

Tayyip Erdoğan also pointed out that"the scale of trade exchange is insufficient, considering the fact that Turkey and Poland have a combined population of more than 100 million". He added that Turkey, just like Poland, wants to use coal in the energy industry (wiadomosci. 
com, 2017). Referring to issues related to energy policy, President Andrzej Duda expressed his conviction that cooperation in this field would develop extensively, especially in the sphere of renewable energy, and, to a lesser extent, in the area of coal mining and climate protection (biznesalert.pl, 2017).

The analysis of Polish-Turkish relations shows that what makes it difficult for small and medium enterprises to establish cooperation are, first of all, lengthy and bureaucratic procedures for Turkish citizens' getting a visa to Poland and the small number and high cost of air connections between both countries. Currently, there are only five connections available between Warsaw and Istanbul, while the Turkish side believes that two or three times as many are needed. There is no doubt that the higher frequency of flights would reduce inflated ticket prices. President Erdoğan proposed that a number of flights be increased and new destinations, such as Kraków or Łódź, be established" (Rogozik, 2017). He stressed that favorable conditions for private business must be created, for example, by curbing bureaucracy and increasing the number of air connections between Poland and Turkey. Poland has a network of airports with little traffic and unused potential, e.g. Wrocław, Bydgoszcz, Poznań, Gdańsk, etc. Turkish Airlines (THY) is in turn one of the best airlines in the world with a huge fleet of modern aircraft. The Polish president pointed out, however, that while he was in favor of the idea of increasing the number of air connections between the two countries, he would like both carriers - Polish LOT and Turkish Airlines - to draw identical benefits from it. It should be mentioned here that air transport between Poland and Turkey has been regulated by the bilateral agreement of 1967 . Under its provisions, flights between the two countries can be operated only by the so-called "appointed carriers" (LOT and THY), and the frequency of flights and the number of seats offered must be the same (Śniedziewski, 2017).

What is more, President Duda thanked the Turkish side for its financial contribution towards the restoration of Marcello Bacciarelli's painting, "The Treaty of Khotyn", at the Royal Castle in Warsaw. On August 25, 2017, in the Knights' Hall of the Royal Castle in Warsaw, the agreement on the conservation of the painting was signed. Under the agreement, the restoration will be financed by Turkey. As the chief of Polish diplomacy said, "Poland and Turkey have a 600-year history of mutual relations and cooperation. This painting happens to be one of the symbols of successful cooperation, although we have experienced difficult situations as well" (Sławiński, 2017). It is worth mentioning that during one of official meetings it was proposed that a monument to commemorate Polish-Turkish friendship be commemorated (TVP Info, 2017a). It was also pointed out that the implementation of this project is important for both nations so that future generations would remember about the centuries-old friendship between both countries. In Turkey, the Polish village of Adampol (Tur. Polonezköy) - which is still inhabited - remains to be the symbol of Poland (Marszałek-Kawa, Burak, 2016).

During President of Turkey R.T. Erdoğan's stay in Poland in October, his meeting with Polish Prime Minister Beata Szydło did not come off. The government’s spokesman, Rafał 
Bochenek explained that the decision to cancel the meeting was related to the "internal situation in Turkey and the necessity of President Erdoğan's personal involvement" (Dziubka, 2017). However, Erdoğan met with Marshal of the Sejm, Marek Kuchciński. The main subjects of the talks were: regional cross-Schengen cooperation, trade exchange, industrial cooperation, and cooperation within the framework of the NATO and in the fields of tourism and infrastructure. The marshal assured that "we are aware that, in this part of the world, it is not possible to guarantee security for citizens without Turkey". Kuchciński also declared his support in developing friendly and efficient parliamentary cooperation (Olejnik, 2017).

As it was mentioned before, the Polish opposition politicians and mass media explicitly criticized the decision to organize President Erdoğan's visit in Poland. A deputy of Civic Platform, Sławomir Nitras, demanded that the Council of Ministers, which is constitutionally responsible for implementing Polish foreign policy, present to the Sejm of the RP its position on the "European relations with Turkey" (tvn24, 2017a). Rafał Trzaskowski, member of the European Parliament from Civic Platform, in an interview in TVN24 channel, made the following comment on Erdoğan's visit in Poland: "by inviting President Erdoğan after a putsch, when 50 thousand people have been imprisoned, Law and Justice shows that it seeks allies who would fit in its political vision" He added that "Poland is the first EU state to have invited the Turkish leader after the failed coup détat of 2016" (tvn24, 2017 b).

On October 18, 2017, in an interview in Radio Zet the president's spokesman, Krzysztof Łapiński, expressed a different opinion on the visit of the Turkish delegation in Poland. When asked about the "dubious" circumstances of Erdoğan's stay in Poland in light of the coup d'état in this country, Łapiński replied: "the circumstances were not dubious when Erdoğan was invited to G20 summit in Germany and talked to Angela Merkel; they were not dubious when he talked to Donald Tusk, Jean Claude Juncker and the president of France" (dziennik.pl, 2017b).

Erdoğan's visit in Poland was also negatively assessed by journalist Thomas Orchowski. His article, entitled "Erdoğan in Poland. A harmful and morally unjustifiable visit", was published by the Polish daily newspaper, "Gazeta Wyborcza". Orchowski wrote: "why should the European Union be confirmed in its conviction that the government of Law and Justice is non-liberal? Berlin may even feel additionally annoyed by Polish-Turkish "flirts", because as many as a few thousand Turkish secret service informers operate in Germany, and Erdoğan compared the German authorities to the Nazis. Thus, a visit of the disgraced dictator in Poland and a warm welcome he received may harm our relations with other partners, who are key for us" (Orchowski, 2017). The spokeswoman for Together Party (pl. Partia Razem), Dorota Olko, spoke in a similar vein in an interview given to "Gazeta Wyborcza". She said that it was "an outrage to receive a man responsible for introducing such a cruel regime with full honors. We believe that the government is doing Erdoğan a favor, legitimizing his brutal policy thanks to this meeting. We do not accept it" (RadioZET.pl, 2017).

On October 17 2017, in front of the Presidential Palace, a few dozen people protested against President Erdoğan's visit in Warsaw. The demonstration was organized by, among 
others, left-wing circles (Polish Initiative, Together Party, the Greens, Women's Warsaw Strike, Feminist Initiative, Lefties' Club) (wolnosc24.pl, 2017). According to the organizers, President Erdoğan is a dictator and an expert in such fields as: 'How to change the constitution in order to rule forever?', 'How to finish off the secular state?, 'Why are women worse than men?', 'How to make the electoral law less democratic quietly?' (Wieczorkiewicz, 2017).

\section{Summary}

As the representatives of the Turkish government administration emphasize, in a difficult internal situation after the coup d'état of July 15, 2016, Turkey is trying to cope with its problems by implementing the stabilization process in the country in which almost three million refugees (mostly from Syria and Iraq) are presently staying. According to the Turkish officials, the unstable situation in the Middle East region negatively affects their country's economy and has caused a number of political problems. In the sphere of foreign policy, the government in Ankara is grappling with the conflict with the European Union and the USA (the so-called visa conflict). As the result of these tensions, Turkey is modifying vectors of its foreign policy, seeking new allies on the international arena in the East. It should be emphasized that on June 24, 2018, the presidential election, which was of utmost importance for President Erdoğan, was held in Turkey. Under the new constitution of the Republic of Turkey the parliamentary system changed into the presidential one. The results of the last election for the head of state allow Erdoğan to hold the office of President until 2024. In addition to our deliberations, it is worth mentioning here that 2023 marks a symbolic date for the Turkish nation - this will be the centenary of the Republic of Turkey (MarszałekKawa, Burak, 2017b).

To conclude our discussion, it must be pointed out that the meeting of the President of the Republic of Turkey, Recep Tayyip Erdoğan, with the President of the Republic of Poland, Andrzej Duda, was of paramount importance for Turkey. According to Turkish commentators, Poland's political, economic and cultural support in such a difficult time for Turkey showed the government in Ankara that Poland may be Turkey's ally in the European Union. What was the tangible result of the visit was, as it was mentioned before, the signing of five important agreements.

To conclude, the Polish-Turkish talks held in Warsaw in October proved that there is space for political dialogue between the two countries. What must be emphasized, the Turkish authorities' interest in the renewal of political relations was officially manifested in the priority given to the visit and its wide coverage in mass media. It was agreed that, on the basis of traditionally friendly relations, Poland should support Turkey"s position on the main issues of cooperation and détente in Europe in order to develop comprehensive Turkish-Polish cooperation and to secure Polish interests in Turkey. The visit in Warsaw has shown that Turkey is keenly interested in Poland"s greater involvement in the implementation of its economic programmes and in the further development of trade exchange, 
provided, however, that Turkey"s trade deficit is reduced. Both sides agreed that cultural and informational activities should be aimed at promoting Poland"s achievements among the Turkish society.

On a final note, relations between Poland and Turkey, despite a number of differences and cooling in mutual relations, should be deemed friendly in general. Both countries have a common, unusual history, and are currently looking for their new paths that would guarantee their stability and development. Although President Recep Tayyip Erdoğan and his policy are criticized in Poland, his stay in Warsaw undoubtedly contributed to the strengthening of amicable relations between the two countries.

\section{References}

Anadolu Ajansı. (2017, October 17). Polonya ile 10 milyar dolarlik ticaret hedefi. Retrieved from: http:// aa.com.tr/tr/dunya/polonya-ile-10-milyar-dolarlik-ticaret-hedefi/940252?amp=1.

biznesalert.pl. (2017, October 18). Prezydent zachęca Turcję do wspótpracy w energetyce. Retrieved from: http://biznesalert.pl/prezydent-zacheca-turcje-wspolpracy-energetyce/.

Burak, A. (2015). Euroazjatycka Wspólnota Gospodarcza i Szanghajska Organizacja Wspótpracy jako alternatywa dla Turcji wobec braku członkostwa w Unii Europejskiej. Nowa Polityka Wschodnia, vol. 9, No. 2, pp. 56-66.

CNN Türk. (2017a, October 9). Erdoğan’ Sirbistan'da 3 bin polis koruyacak. Retrieved from: https:// www.cnnturk.com/turkiye/Erdoğani-sirbistanda-3-bin-polis-koruyacak.

CNN Türk. (2017b, October 9). İște ABD ile Türkiye arasındaki vize krizinin nedeni. Retrieved from: https://www.cnnturk.com/turkiye/iste-abd-ile-turkiye-arasindaki-vize-krizini-atesleyen-isim.

DW. (2017a, March 4). О чем спорят Германия и Туриия. Retrieved from: http://www.dw.com/ $\mathrm{ru} / \mathrm{a}-37810363$.

DW. (2017b, October 17). Erdoğan z wizytą w Polsce. „Poznać turecka optykę”. Retrieved from: http://www.dw.com/pl/Erdoğan-z-wizyt\%C4\%85-w-polsce-pozna\%C4\%87-tureck\%C4\%85optyk\%C4\%99/a-40979287.

dziennik.pl. (2017a, May 14). Premier Beata Szydło spotkała się z prezydentem Turcji. „Wyraził duże zainteresowanie inwestycjami w Polsce". Retrieved from: http://wiadomosci.dziennik.pl/swiat/ artykuly/549699,chiny-beata-szydlo-tayyip-recep-Erdoğan.html.

dziennik.pl. (2017b, October 18). Łapiński ocenił wizytę prezydenta Turcji w Polsce. Zdradził, o czym Andrzej Duda rozmawiał $z$ Erdoğanem. Retrieved from: http://wiadomosci.dziennik.pl/polityka/ artykuly/560607,wizyta-Erdoğana-w-polsce-ocena.html.

Dziubka, K. (2017, October 17). KPRM: Spotkanie premier Szydło z Erdoğanem zostało odwołane. Retrieved from: http://wiadomosci.gazeta.pl/wiadomosci/7,114884,22526282,kprm-spotkaniepremier-szydlo-z-Erdoğanem-zostalo-odwolane.html.

gazetaprawna.pl. (2017, October 17). Erdoğan do Dudy: Jeżeli nie chcecie nas w UE, powiedzcie nam o tym. Retrieved from: http://www.gazetaprawna.pl/artykuly/1078740,wizyta-ergogana-w-polsce. html.

gospodarkamorska.pl. (2017, October 17). Prezydent: Polska popiera starania Turcji o wstapienie do 
UE. Retrieved from: http://www.gospodarkamorska.pl/Administracja,Prawo/prezydent:-polskapopiera-starania-turcji-o-wstapienie-do-ue.html.

Habertürk. (2017a, October 17). Cumhurbaşkanı Erdoğan, Polonya'ya gitti. Retrieved from: http://www. haberturk.com/cumhurbaskani-Erdoğan-polonya-ya-gitti-1675284.

Habertürk. (2017b, October 17). "İş adamlarımızı Polonya'ya davet ediyorum.” Retrieved from: http:// www.haberturk.com/cumhurbaskani-Erdoğan-turk-is-adamlarini-polonya-ya-davet-etti-1676073ekonomi.

Kamalov, İ., Kanbolat, H. (2012). Türkiye-Ukrayna İlişkileri. İstanbul: Veritas Yayıncılık. lenta.ru. (2017, October 9). Эрдоган пообещал Порошенко не признавать присоединение Крыма $\kappa$ Poccuu. Retrieved from: https://lenta.ru/news/2017/10/09/Erdoğan/.

Marszałek-Kawa, J., Burak, A. (2016). Polonezköy. Kultura i Edukacja, No. 2 (112), pp. 9-26.

Marszałek-Kawa, J., Burak, A. (2017a). The Landscape after Brexit as Seen from Ankara. Will the UK's Divorce from the European Union Additionally Loosen Tights Between Europe and Turkey and Have an Impact on the Future of the Continent?. Political Science Review, No. 3, pp. 117-126.

Marszałek-Kawa, J., Burak, A. (2017b). The Republic of Turkey. The Constitution, Parliament, Election and Democracy Issues. Toruń: Wydawnictwo Adam Marszałek.

Ministerstwo Rodziny, Pracy i Polityki Społecznej. (2017, October 17). Umowa o zabezpieczeniu społecznym $z$ Turcja. Retrieved from: https://www.mpips.gov.pl/aktualnosci-wszystkie/ art,5528,9354,umowa-o-zabezpieczeniu-spolecznym-z-turcja.html.

niezalezna.pl.(2017a, October 17). PO potępia zaproszenie Erdoğana. Zapomnieli, kto jeszcze niedawno przyjmowat prezydenta Turcji?. Retrieved from: http://www.dzienniklodzki.pl/aktualnosci/a/recepErdoğan-w-polsce-witany-z-honorami-opozycja-krytykuje-zaproszenie-prezydenta-turcji,12589034/. niezalezna.pl. (2017b, October 17). Prezydent Erdoğan w Polsce: podpisano aż pięć ważnych umów międzyrządowych. Retrieved from: http://niezalezna.pl/206144-prezydent-Erdoğan-w-polscepodpisano-az-piec-waznych-umow-miedzyrzadowych.

Olejnik, M. (2017, October 18). Marszałek Sejmu: W tej części świata bez Turcji nie ma możliwości zapewnienia bezpieczeństwa obywatelom. Retrieved from: http://www.marekkuchcinski.pl/ wydarzenia/marszalek-sejmu-tej-czesci-swiata-bez-turcji-mozliwosci-zapewnienia-bezpieczenstwaobywatelom/.

Orchowski, T. (2017, October 17). Erdoğan w Polsce. Wizyta szkodliwa i moralnie nie do obrony. Retrieved from: http://wyborcza.pl/osiemdziewiec/7,159012,22527759,Erdoğan-w-polsce-wizyta-s zkodliwa-i-moralnie-nie-do-obrony.html.

polskieradio.pl. (2017, October 17). Prezydent: Polska popiera starania Turcji o wstapienie do UE. Retrieved from: https://www.polskieradio.pl/5/3/Artykul/1890486,Prezydent-Polska-popiera-staraniaTurcji-o-wstapienie-do-UE.

premier.gov.pl. (2009, May 14). Strategiczna wspótpraca Polski i Turcji. Retrieved from: https://www. premier.gov.pl/wydarzenia/aktualnosci/strategiczna-wspolpraca-polski-i-turcji.html.

prezydent.pl.(2017a,April 24). Prezydent odbyt rozmowę telefoniczną z prezydentem Turcji. Retrieved from: http://www.prezydent.pl./aktualnosci/wydarzenia/art,583,prezydent-odbyl-rozmowe-telefoniczna-z-prezydentem-turcji-html.

prezydent.pl. (2017b, October 17). Spotkanie prezydentów Polski i Turcji z mediami. Wystąpienie prezydenta Andrzeja Dudy. Retrieved from: http://www.prezydent.pl/aktualnosci/wypowiedziprezydenta-rp/wystapienia/art,298,spotkanie-prezydentow-polski-i-turcji-z-mediami-wystapienieprezydenta-andrzeja-dudy.html. 
prezydent.pl. (2017c, October 17). Wizyta Prezydenta Turcji PL/ENG. Retrieved from: http://www. prezydent.pl/aktualnosci/wydarzenia/art,768,wizyta-prezydenta-turcji.html.

Program realizacji umowy między Rządem Rzeczypospolitej Polskiej a Rządem Republiki Turcji o wspótpracy w dziedzinach nauki, oświaty i kultury na lata 2003-2006, podpisany w Ankarze dnia 7 kwietnia 2003 r. (2004). Dziennik Ustaw, No. 41, Item 383, pp. 2301-2310.

RadioZET.pl. (2017, October 17). Erdoğan w Polsce. W planach spotkania $z$ Duda i Szydło oraz... protest przed Pałacem. Retrieved from: http://wiadomosci.radiozet.pl/Polska/Prezydent-TurcjiRecep-Erdoğan-z-wizyta-w-Warszawie.

Regnum. (2017, October 11). Эрдоган и Вучич обсудили «Туреикий поток» и товарооборот Туризи и Сербии. Retrieved from: https://regnum.ru/news/2332569.html.

Rogozik, M. (2017, October 19). Prezydent Erdoğan proponuje więcej lotów z Turcji. Tym razem do Krakowa. Retrieved from: http://www.gazetakrakowska.pl/strefa-biznesu/a/prezydent-Erdoğanproponuje-wiecej-lotow-z-turcji-tym-razem-do-krakowa,12597000/.

Rzeczpospolita. (2017, October 17). Andrzej Duda z prezydentem Turcji o wojsku i kulturze. Retrieved from: http://www.rp.pl/Dyplomacja/171019027-Andrzej-Duda-z-prezydentem-Turcji-o-wojsku-i-kulturze.html.

Sabah. (2017a, October 9). ABD vizeleri neden durdurdu? - Amerika Türkiye’ye Vize başvurularını neden durdurdu? - İste ayrintılar. Retrieved from: http://www.sabah.com.tr/dunya/2017/10/09/ abd-turkiyeye-vize-basvurularini-neden-durdurdu-skandal-karar.

Sabah. (2017b, October 18). Dede Efendi sürprizi. Retrieved from: http://www.sabah.com.tr/gundem/2017/10/18/dede-efendi-surprizi.

Sławiński, M. (2017, August 25). Podpisano porozumienie ws. konserwacji obrazu Marcella Bacciarellego "Pokój chocimski”. Retrieved from: http://dzieje.pl/kultura-i-sztuka/podpisano-porozumieniews-konserwacji-obrazu-marcella-bacciarellego-pokoj-chocimski.

Sputnik. (2017a, March 13). 9 açıklamayla Türkiye-Hollanda krizi. Retrieved from: https://tr.sputniknews. com/haberler/201703131027613986-turkiye-hollanda-kriz-referandum-Erdoğan/.

Sputnik. (2017b, September 5). Отношения ЕС с Туриией: в ожидании, кто первым «хлопнет» дверью. Retrieved from: https://ru.sputnik-news.ee/news/20170905/7021651/Otnoshenija-ES-Turciejigra-odni-vorota.html.

Śniedziewski, T. (2017, October 18). Prezydent Turcji chce więcej lotów do Polski. Retrieved from: http:// www.pasazer.com/news/36459/prezydent,turcji,chce,wiecej,lotow,do,polski.html.

tass.ru. (2017, October 10). Эрдоган обсудит в Сербии «Туреикий поток» и пошлет сигнал поддержки балканским мусульманам. Retrieved from: http://tass.ru/mezhdunarodnayapanorama/4631584.

Traktat o Przyjaźni między Polska a Turcją (The Treaty on Polish-Turkish Friendship, approved by the act of 5 December 1923) (1924). Dziennik Ustaw, No. 39, Item 407, pp. 605-607.

TRT Haber. (2017, October 15). İş dünyasının gözü Cumhurbaşkanı Erdoğan’n Polonya ziyaretinde. Retrieved from: http://www.trthaber.com/haber/gundem/is-dunyasinin-gozu-cumhurbaskaniErdoğan-in-polonya-ziyaretinde-337959.html.

Türkiye Cumhuriyeti Cumhurbaşkanlığı. (2017a, October 6). Venezuela Cumhurbaşkanı Maduro Cumhurbaşkanlı̆̆ı Külliyesinde. Retrieved from: https://www.tccb.gov.tr/haberler/410/84821/ venezuela-cumhurbaskani-maduro-cumhurbaskanligi-kulliyesinde.html.

Türkiye Cumhuriyeti Cumhurbaşkanlığı. (2017b, October 9). Cumhurbaşkanı Erdoğan Ukrayna’da. 
Retrieved from: https://www.tccb.gov.tr/haberler/410/84860/cumhurbaskani-Erdoğan-ukraynada. html.

Türkiye Cumhuriyeti Cumhurbaşkanlı̆̆ı. (2017c, October 10). Cumhurbaşkanı Erdoğan Sırbistan'da.

Retrieved from: https://www.tccb.gov.tr/haberler/410/84873/cumhurbaskani-Erdoğan-sirbistanda. html.

tvn24. (2017a, October 25). Marszałek Sejmu zwróci się o informację w sprawie wizyty Erdoğana. Re-

trieved from: https://www.tvn24.pl/wiadomosci-z-kraju,3/marszalek-sejmu-wnioskuje-o-informacjerzadu-ws-wizyty-Erdoğana,784399.html.

tvn24. (2017b, October 17). "Zaproszenie Erdoğana do Polski po puczu ma wymiar symboliczny."

Retrieved from: https://www.tvn24.pl/wiadomosci-z-kraju,3/rafal-trzaskowski-w-jeden-na-jedeno-wizycie-Erdoğana-w-polsce,781982.html.

TVP Info. (2017a, October 1). Erdoğan: nie potrzebujemy już członkostwa w Unii Europejskiej. Retrieved from: http://www.tvp.info/34217254/Erdoğan-nie-potrzebujemy-juz-czlonkostwa-w-unii-europejskiej. TVP Info. (2017b, October 17). Prezydent Duda: Polska popiera starania Turcji o wstapienie do UE. Retrieved from: https://www.tvp.info/34426659/prezydent-duda-polska-popiera-starania-turcjio-wstapienie-do-ue.

Układ o przyjaźni i współpracy między Rzeczapospolita Polską a Republiką Turecka, sporządzony $w$ Warszawie dnia 3 listopada 1993 r. (The Treaty on Friendship and Cooperation between the Republic of Poland and the Republic of Turkey, signed in Warsaw on 3 November 1993) (1995). Dziennik Ustaw, No. 118, Item 566, pp. 2706-2707.

wiadomosci.com. (2017, October 17). Prezydent Turcji Recep Tayyip Erdoğan podziękowat za ciepłe przyjęcie w Polsce. Retrieved from: http://wiadomosci.com/prezydent-turcji-recep-tayyip-Erdoğanpodziekowal-cieple-przyjecie-polsce/.

Wieczorkiewicz, P. (2017, October 16). Erdoğan z wizyta w Warszawie. Organizacje lewicowe zapowiadaja protest: “To polityk, który zawiesił prawa człowieka”. Retrieved from: http://warszawa. wyborcza.pl/warszawa/7,54420,22521625,Erdoğan-z-wizyta-w-warszawie-organizacje-lewicowe-z apowiadaja.html.

wolnosc24.pl. (2017, October 18). Goryle Erdoğana zaatakowali polskich demonstrantów na Placu Piłsudskiego. Wyrywali im transparenty. Retrieved from: http://wolnosc24.pl/2017/10/18/ goryle-Erdoğana-zaatakowali-polskich-demonstrantami-na-placu-pilsudskiego-wyrywali-im-tran sparenty-wideo/.

wPolityce.pl. (2017, October 17). Prezydent Turcji przylatuje do Polski. To pierwsza wizyta Erdoğana w kraju unijnym po „puczu”. Środowiska lewicowe zapowiadaja protesty. Retrieved from: https:// wpolityce.pl/polityka/362677-prezydent-turcji-przylatuje-do-polski-to-pierwsza-wizyta-Erdoğanaw-kraju-unijnym-po-puczu-srodowiska-lewicowe-zapowiadaja-protesty.

Бухарова, М. (2017, Мау 24). НАТО теряет друга: Туриия наложила вето на сотрудничество альянса с Австрией. Retrieved from: https://russian.rt.com/world/article/393005-avstriya-natopartner-turciia.

Газета.ru. (2017, October 6). Эрдоган рассказал о встрече с Мадуро. Retrieved from: https://www. gazeta.ru/politics/news/2017/10/06/n_10660928.shtml.

Дорош, С. (2017, October 9). Эрдоган будет говорить в Киеве о Крыме и maтарах. Retrieved from: http://www.bbc.com/ukrainian/features-russian-41550194.

ИноСМИ.ru. (2017, October, 13). Россия ответила на слова Эрдогана о Крыме. Retrieved from: http://inosmi.ru/politic/20171013/240519384.html. 
Мансилья, А.С. (2017, October 10). Венесуэла не в одиночестве. Retrieved from: http://inosmi.ru/ politic/20171010/240480135.html.

РИА Новости. (2017, October 6). Мадуро рассказал о стремлении Туриии и Венесуэльк к многополярному миру. Retrieved from: https://ria.ru/world/20171006/1506355088.html.

\section{Authors}

\section{Joanna Marszałek-Kawa}

Nicolaus Copernicus University in Toruń, Faculty of Political Science.

Contact details: kawadj@box43.pl

\section{Ahmet Burak}


